\title{
EKSTRAKSI SENYAWA BIOAKTIF CABAI RAWIT (CAPSICUM FRUTESCENS L.) MENGGUNAKAN METODE EKSTRAKSI GELOMBANG ULTRASONIK
}

\section{Extraction of Bioactive Compound in Chilli Pepper (Capsicum frutescens L.) with Ultrasonic Asissted Extraction Methods}

\author{
Joni Kusnadii ${ }^{1}$ Dian Wuri Andayani ${ }^{1}$, Elok Zubaidah ${ }^{1}$, Estri Laras Arumingtyas ${ }^{2}$ \\ 1Jurusan Teknologi Hasil Pertanian - Fakultas Teknologi Pertanian - Universitas Brawijaya \\ 2Jurusan Biologi - Fakultas Matematika dan Ilmu Pengetahuan Alam - Universitas Brawijaya \\ Jalan Veteran, Malang 65145 \\ *Penulis Korespondensi, email: dianwuriandayani@gmail.com
}

Disubmit: 6 September 2017 Direvisi: 29 April 2019 Diterima: 22 Juni 2019

\begin{abstract}
ABSTRAK
Cabai rawit (Capsicum frutenses L.) memiliki kandungan senyawa bioaktif seperti capsaicinoid, fenol, flavonoid dan vitamin $\mathrm{C}$ yang tinggi, sehingga berpotensi sebagai sumber antioksidan. Tujuan penelitian ini untuk mengetahui pengaruh rasio bahan:pelarut dan lama ekstraksi dengan gelombang ultrasonik/Ultrasonic Assisted Extraction (UAE) terhadap kandungan fitokimia dan aktivitas antioksidan dari ekstrak cabai rawit. Faktor rasio bahan:pelarut (1:5; 1:10; dan 1:15) dan lama waktu ekstraksi (5, 10, dan 15 menit) diamati agar diperoleh karakteristik ekstrak cabai rawit terbaik. Hasil penelitian menunjukkan bahwa rasio bahan:pelarut dan lama waktu ekstraksi memberikan pengaruh nyata terhadap kandungan capsaicinoid, total fenol dan flavonoid. Perlakuan terbaik metode ekstraksi UAE diperoleh dari perbandingan bahan:pelarut $=1: 10$ dan lama waktu ekstraksi 15 menit dengan kandungan capsaisin 102,89 mg/g bk, total fenol 56,75 mg $\mathrm{GAE} / \mathrm{g}$ bk, total flavonoid 208,89 mg QE/g bk dan kandungan vitamin C 27,57 mg/g bk.
\end{abstract}

Kata kunci: Bioaktif; Cabai Rawit; Ekstraksi; Ultrasonik

\begin{abstract}
Chilli pepper (Capsicum frutenses L.) has high content of bioactive compounds such as capsaicinoid, phenol, flavonoids and vitamin C, so that potentially as a source of antioxidants. The aim of this study to determine the effect of materials:solvent and extraction time of ultrasonic assisted extraction (UAE) to phytochemical content and antioxidant activity of the chilli pepper extract. The ratio of material:solvent (1:5; 1:10; and 1:15) and time of extraction $(5,10$, dan $15 \mathrm{~min})$ were observed to obtain the best characteristics of chilli pepper extract. The results showed that the ratio of material:solvent and time of extraction gave a significant effect on capsaicinoid content, total phenol and flavonoids. The best treatment was obtained from the material:solvent ratio of 1:10 and extraction time of 15 minutes with capsaisin content of $102.89 \mathrm{mg} / \mathrm{g} \mathrm{dw}$, total phenol of $56.75 \mathrm{mg} \mathrm{GAE} / \mathrm{g} d w$, total flavonoid of $208.89 \mathrm{mg}$ QE/g dw and vitamin C of $27.57 \mathrm{mg} / \mathrm{g} \mathrm{dw}$.
\end{abstract}

Keyword: Bioactive; Chilli Pepper; Extraction; Ultrasonic 


\section{PENDAHULUAN}

Cabai merupakan komoditas rempah komersial dalam perdagangan dunia, karena kelebihannya dalam hal warna, aroma, rasa dan kepedasan. Tingkat kepedasan cabai dipengaruhi oleh kandungan senyawa capsaicinoid (khususnya capsaicin dan dihidrocapsaicin). Capsicum frutescens (cabai rawit) memiliki kandungan capsaisinoid yang lebih tinggi daripada cabai jenis lainnya (Barbero et al., 2008). Cabai rawit juga memiliki kandungan vitamin $\mathrm{C}$ yang lebih tinggi dibandingkan cabai merah, ataupun buahbuahan seperti mangga, jeruk, nanas, apel, tomat, belimbing, dan buah lainnya (Depkes, 2005). Selain itu, kandungan senyawa fitokimia pada cabai rawit juga beragam seperti tanin, flavonoid, alkaloid, antraquinon, fenol, saponin, glikosida, terpenoid, limonoid dan karotenoid (Emmanuel-Ikpeme et al., 2014). Lebih lanjut, Zhuang et al. (2012) menunjukkan kandungan total fenol cabai rawit lebih tinggi dibandingkan cabai dari golongan Capsicum annuum.

Potensi senyawa kimia dalam cabai rawit dapat dimanfaatkan secara optimal dalam bentuk ekstrak cabai. Beberapa penelitian menunjukkan bahwa ekstrak cabai rawit dapat digunakan sebagai pereda mual, muntah dan sakit tenggorokan pasca operasi pengangkatan rahim (Kim et al., 2002 dan Park et al., 2004), antidiabetes dan antioksidan (Sricharoen et al., 2016; Nascimento et al., 2014), antimikroba (Gurnani et al., 2016), analgesik (Knotkova et al., 2008), antikanker (Yang et al., 2010), antiinflamatory (Zimmer et al., 2012), pengatur berat badan (Whitting et al., 2012), pengatur sistem kardiovaskular dan sistem pencernaan (Luo et al., 2011).

Salah satu faktor yang berpengaruh dalam menentukan karakteristik ekstrak cabai rawit adalah metode ekstraksi (Boonkird et al. 2008, Gurnani et al., 2016). Saat ini, metode ekstraksi non konvensional mendapatkan perhatian karena memiliki kelebihan dalam hal waktu lebih singkat, penggunaan pelarut lebih sedikit, hasil lebih melimpah serta kualitas kandungan senyawa kimia lebih baik dibandingkan metode konvensional (Azmir et al., 2013). Metode ekstraksi non konvensional yang telah digunakan dalam proses ekstraksi cabai rawit antara lain ekstraksi dengan bantuan gelombang mikro/Microwave Assisted Extraction/MAE (Gurnani et al., 2016), dengan bantuan gelombang ultrasonik/Ultrasound Assisted Extraction/MAE (Barbero et al., 2008) dan menggunakan fluida (karbondioksida) super kritis (de Aguiar et al., 2013). Diantara metode-metode ekstraksi tersebut, metode UAE lebih menjanjikan dari segi ekonomi karena lebih murah, lebih sederhana dan efisien. Selain itu, peningkatan rendemen, selektivitas, kecepatan ekstraksi serta kualitas senyawa fitokimia dalam ekstrak juga telah ditunjukkan oleh kedua metode ekstraksi tersebut (Alupului, 2012).

Agar proses ekstraksi berjalan efisien, maka faktor rasio bahan dibanding pelarut serta lama waktu ekstraksi harus ditentukan dengan tepat. Hal tersebut disebabkan karena rasio bahan dibanding pelarut serta lama waktu ekstraksi akan berpengaruh terhadap jumlah kandungan senyawa bioaktif yang dapat terekstrak. Oleh karena itu, perlu dilakukan penelitian untuk mengetahui lama waktu ekstraksi dan rasio bahan dibanding pelarut yang tepat agar diperoleh karakteristik ekstrak cabai rawit yang memiliki kandungan senyawa bioaktif tertinggi diantara kombinasi kedua perlakuan tersebut.

\section{METODE}

Bahan baku yang digunakan adalah cabai rawit yang dibeli di pasar lokal Malang. Cabai rawit tersebut dicuci dengan air bersih mengalir, kemudian dikeringkan. Selanjutnya, cabai rawit yang telah bersih disimpan dalam refrigerator suhu $4{ }^{\circ} \mathrm{C}$ hingga dilakukan proses ekstraksi. Pelarut yang digunakan dalam proses ekstraksi adalah etanol (Merck), sedangkan bahan yang digunakan dalam analisis kimia antara lain standar capsaicin (ChemFaces), standar asam galat, Folin-Ciocalteu, $\mathrm{Na}_{2} \mathrm{CO}_{3}$, standar quercetin, $\mathrm{NaNO}_{3}, \mathrm{NaOH}$, standar asam askorbat, asam sitrat, natrium hipoklorat, natrium oksalat (Merck), $\mathrm{AlCl}_{3}$ (LIPI), DPPH (Sigma), dan aquades.

Alat yang digunakan dalam proses ekstraksi adalah blender (Philips), timbangan analitik (Galaxy 400), oven kering (Memmert), ultrasound tipe probe (ColePalmer/CPX 130) dengan tegangan 220 $\mathrm{V}$ dan daya $130 \mathrm{~W}$, termometer, vacum rotary evaporator (IKA RV 10 digital), sedangkan alat yang digunakan untuk analisa kimia adalah 
neraca analitik (Mattler AE 160), desikator, vortex (Super Mixer II no. 1190-1), dan spektrofotometer UV-Vis (JenWay).

\section{Rancangan Percobaan}

Rancangan percobaan dalam penelitian ini adalah rancangan acak kelompok (RAK) faktorial dengan 2 faktor. Faktor pertama adalah lama ekstraksi yang terdiri dari 3 level yaitu 5, 10 dan 15 menit. Sedangkan faktor kedua adalah rasio jumlah bahan:pelarut yang terdiri dari 3 level yaitu 1:5, 1:10 dan 1:15. Kombinasi perlakuan tersebut diulang sebanyak 3 kali sehingga diperoleh 27 satuan percobaan. Perlakuan yang memiliki kandungan capsaicinoid, total fenol, total flavonoid dan vitamin $C$ tertinggi berdasarkan metode mutiple atribut dianggap sebagai perlakuan terbaik (Zeleny, 1982).

\section{Tahapan Penelititan}

Proses Ekstraksi

Peralatan yang digunakan adalah ultrasonik tipe tanduk getar (Cole Palmer/CPX 130) dengan frekuensi $20 \mathrm{kHz}$, amplitudo $60 \%$. Sedangkan setelan waktu yang digunakan adalah 15 menit dengan jeda setiap 1 menit. Filtrat yang diperoleh dari proses ekstraksi disaring dan kemudian dipekatkan menggunakan vacum rotary evaporator dengan kecepatan $40 \mathrm{rpm}$ dan suhu $40{ }^{\circ} \mathrm{C}$. Selanjutnya dilakukan penyemprotan gas $\mathrm{N}_{2}$ untuk menguapkan sisa etanol. Filtrat kental tersebut kemudian disimpan dalam refrigerator hingga digunakan pada analisis selanjutnya.

\section{Pengujian Kandungan Capsaicinoid}

Kandungan capsaisinoid ekstrak cabai rawit diukur menggunakan metode spektrofotometri (Victorija et al., 2013). Standar yang digunakan adalah capsaisin murni dengan konsentrasi 20-100 ppm, sehingga hasil pengujian dinyatakan sebagai kandungan capsaisinoid setara capsaisin. Ekstrak cabai rawit diencerkan dengan etanol hingga diperoleh konsentrasi 400 ppm. Selanjutnya, pengukuran absorbansi dilakukan pada panjang gelombang $280 \mathrm{~nm}$ menggunakan spektrofotometer UV Vis (Shimadzu 1240).

\section{Pengujian Total Fenol}

Total fenol diukur menggunakan metode Folin-Ciaucalteu (de Aguiar et al., 2013). Sebanyak $1 \mathrm{ml}$ sampel/standar ditambah $5 \mathrm{ml}$ larutan Folin-Ciocalteu 10\%, dan didiamkan selama 5 menit. Selanjutnya ditambahkan 5 ml larutan $\mathrm{Na}_{2} \mathrm{CO}_{3} \quad 7,5 \%$ dan divortex. Larutan dibiarkan selama 120 menit dalam kondisi gelap. Pengukuran absorbansi dilakukan pada $\lambda$ max (756 nm) menggunakan spektrofotometer UV Vis (Shimadzu 1240). Standar yang digunakan adalah asam galat murni konsentrasi 20-100 ppm. Hasil dinyatakan dalam $\mathrm{mg}$ setara asam galat per gram berat kering.

\section{Pengujian Total Flavonoid}

Total flavonoid diukur menggunakan metode Aluminium klorida (Atanassova et al., 2011). Sebanyak $1 \mathrm{ml}$ sampel dimasukkan dalam tabung reaksi yang berisi $4 \mathrm{ml}$ aquades. Kemudian ditambahkan $0,3 \mathrm{ml}$ larutan $\mathrm{NaNO}_{3} 5 \%$, dan didiamkan selama 5 menit. Larutan $\mathrm{AlCl}_{3} \quad 10 \%$ ditambahkan sebanyak 0,3 $\mathrm{ml}$, kemudian divortex. Selanjutnya ditambahkan $2 \mathrm{ml}$ larutan $\mathrm{NaOH}$ $1 \mathrm{M}$ dan aquades hingga $10 \mathrm{ml}$. Pengukuran absorbansi dilakukan pada $\lambda$ max $(510 \mathrm{~nm})$. Standar yang digunakan adalah quercetin murni dengan konsentrasi 20-100 ppm. Hasil dinyatakan dalam $\mathrm{mg}$ setara quercetin per gram berat kering.

\section{Pengujian Kadar Vitamin C}

Kadar vitamin $C$ diukur menggunakan metode spektrofotometri (Selimovic et al., 2011). Sampel ditimbang kemudian dilarutkan dalam larutan natrium oksalat sehingga diperoleh konsentrasi $0,4 \mathrm{mg} / \mathrm{ml}$. Pengukuran absorbansi dilakukan pada $\lambda$ $\max (266 \mathrm{~nm})$. Standar yang digunakan adalah asam askorbat murni dengan konsentrasi 20-100 ppm.

\section{Pengujian Aktivitas Antioksidan}

Aktivitas antioksidan diukur menggunakan metode DPPH (modifikasi Vega-Galvez et al., 2009). Sebanyak $1 \mathrm{ml}$ sampel ditambahkan $2 \mathrm{ml}$ larutan DPPH 0,1 $\mathrm{mM}$. Larutan divortex dan dibiarkan selama 30 menit dalam kondisi gelap. Pengukuran absorbansi dilakukan pada $\lambda \max (517 \mathrm{~nm})$. Aktivitas antioksidan dihitung dengan membandingkan absorbansi sampel menggunakan persamaan:

$\%$ Penghambatan $=($ Absorbansi blanko Absorbansi sampel)/Absorbansi blanko $\mathrm{x}$ $100 \%$ 


\section{Analisis statistik}

Semua eksperimen dilakukan sebanyak 3 kali dan data yang dilaporkan adalah data ratarata \pm SD (Standart Deviation). GLM (General Linier Model) anova dengan uji lanjut Tukey digunakan untuk mengetahui tingkat perbedaan masing masing perlakuan dengan menggunakan selang kepercayaan 5\%. Semua analisa statistik diolah menggunakan Minitab 16. Sedangkan penetapan perlakuan terbaik berdasarkan metode mutliple atribut (Zeleny, 1982) yang dihitung menggunakan microsoft excel.

\section{HASIL DAN PEMBAHASAN}

Hasil penelitian pada Gambar 1. menunjukkan bahwa kandungan capsaicinoid berkisar antara 90,36-112,06 mg/g bk, dimana nilai terendah diperoleh dari lama waktu ekstraksi 15 menit dan rasio bahan:pelarut 1:5, sedangkan nilai tertinggi diperoleh dari lama waktu ekstraksi 5 menit dan rasio bahan:pelarut 1:10. Total fenol berkisar antara 46,12-56,75 mg GAE/g bk, dimana nilai terendah diperoleh dari lama waktu ekstraksi 5 menit dan rasio bahan:pelarut 1:5, sedangkan nilai tertinggi diperoleh dari lama waktu ekstraksi 15 menit dan rasio bahan:pelarut 1:10. Total flavonoid berkisar antara 89,84-208,89 $\mathrm{mg}$ QE/g bk, dimana nilai terendah diperoleh dari lama waktu ekstraksi 5 menit dan rasio bahan:pelarut 1:5, sedangkan nilai tertinggi diperoleh dari lama waktu ekstraksi 15 menit dan rasio bahan:pelarut 1:15. Kandungan vitamin $C$ berkisar antara 26,44-27,65 mg/g bk dimana nilai terendah diperoleh dari lama waktu ekstraksi 5 menit dan rasio bahan:pelarut 1:5, sedangkan nilai tertinggi diperoleh dari lama waktu ekstraksi 10 menit dan rasio bahan:pelarut 1:10.

\section{Pengaruh Rasio Bahan:Pelarut}

Hasil analisa ragam menunjukkan bahwa faktor rasio bahan:pelarut berpengaruh nyata terhadap kandungan capsaicinoid, total fenol dan flavonoid ekstrak. Sebaliknya, faktor lama waktu ekstraksi tidak berpengaruh nyata terhadap kandungan vitamin $C$ ekstrak. Rerata kandungan capsaicinoid, total fenol, flavonoid dan vitamin $\mathrm{C}$ ekstrak cabai rawit akibat perbedaan rasio bahan:pelarut dapat dilihat pada Tabel 1. Berdasarkan Tabel 1, terlihat bahwa kandungan capsaicinoid, total fenol dan flavonoid ekstrak meningkat dengan meningkatnya rasio bahan:pelarut hingga perbandingan 1:10, selanjutnya penambahan jumlah pelarut tidak akan memberikan pengaruh yang signifikan terhadap kandungan capsaicinoid. Pola yang sama juga ditunjukkan oleh Bae et al. (2012) dalam mengekstrak capsaisin dari cabai Capsicum annuиm L. varietas Tuxtlas menggunakan metode UAE, dimana hasil meningkat dari perbandingan rasio bahan:pelarut 1:3 hingga 1:8. Begitu juga dengan pola yang ditunjukkan oleh Zhang et al. (2012) dalam proses ekstraksi flavonoid dari Prunella vulgaris L. menggunakan metode UAE. Jumlah pelarut yang sedikit akan menghasilkan total flavonoid yang sedikit pula, dan peningkatan jumlah pelarut akan meningkatkan jumlah flavonoid.

Peningkatan kadar capsaicinoid, total fenol dan flavonoid ekstrak disebabkan karena semakin banyak jumlah pelarut maka perbedaan gradien konsentrasi antara pelarut dan zat terlarut semakin besar. Setelah matriks sel pecah akibat proses kavitasi, maka senyawa capsaicinoid dan fenol akan berdifusi ke dalam pelarut. Semakin besar rasio bahan:pelarut, maka semakin besar perbedaan gradien konsentrasi antara antara pelarut dan cairan sel. Hal tersebut akan mendorong terjadinya proses difusi dan transfer massa dari matriks sel menuju pelarut sampai terjadi kesetimbangan konsentrasi. Hal tersebut juga diungkapkan oleh Xu et al. (2015) yang mengatakan bahwa tingginya rasio bahan:pelarut akan mempercepat transfer massa dan memfasilitasi proses difusi senyawa bioaktif menuju pelarut hingga proses transffer massa mencapai titik maksimum. Dalam penelitian ini, titik maksimum dicapai pada saat rasio bahan:pelarut 1:10. Pada rasio bahan:pelarut 1:10 dan 1:15, kandungan capsaicinoid, total fenol dan flavonoid tidak menunjukkan hasil yang berbeda nyata. Hal ini menandakan bahwa pada rasio 1:10 telah tercapai titik jenuh antara pelarut dan bahan, sehingga penambahan pelarut tidak akan menambah jumlah senyawa yang terekstrak secara signifikan (Pradana et al., 2017). Selain itu, selama proses ekstraksi terjadi peningkatan suhu, dimana suhu akhir ekstraksi berkisar 33-38 ${ }^{\circ} \mathrm{C}$. Adanya peningkatan suhu tersebut dapat mempercepat proses difusi senyawa bioaktif menuju pelarut. 


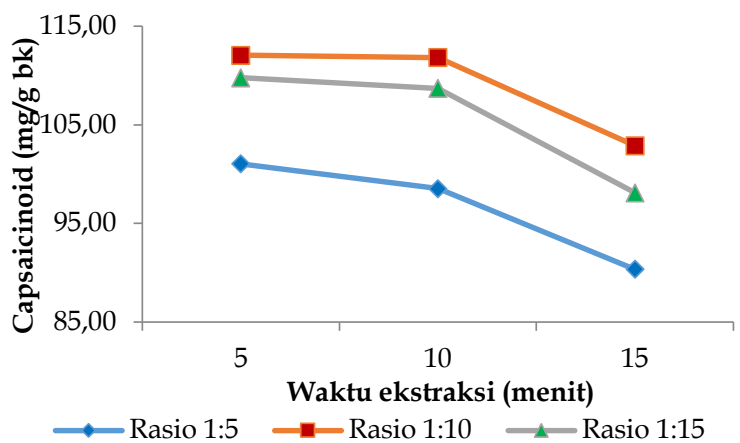

(a)

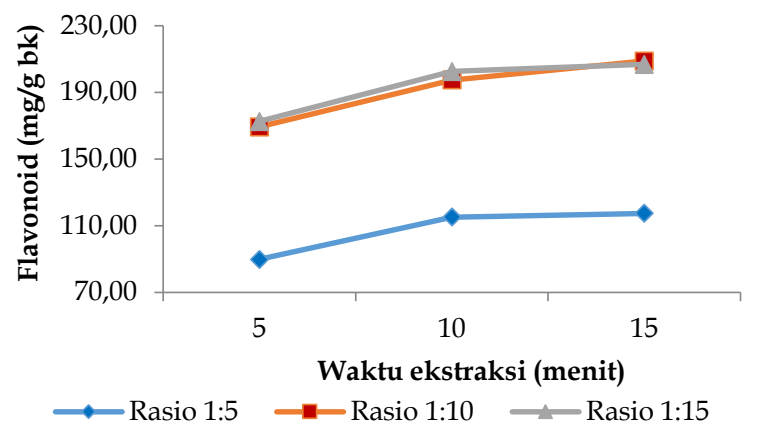

(c)

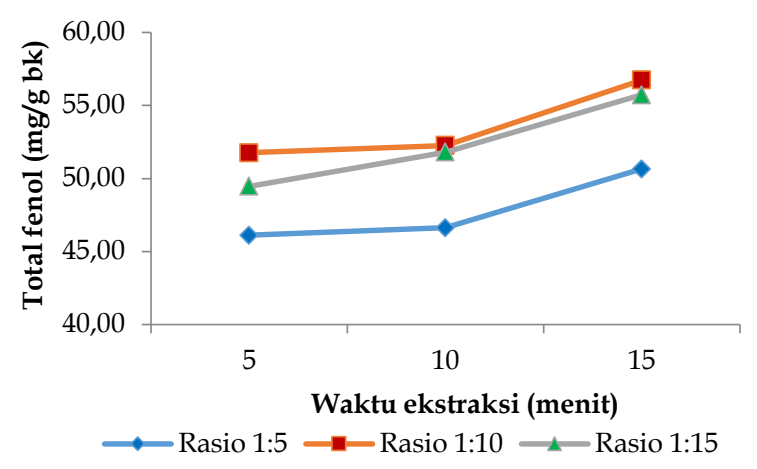

(b)

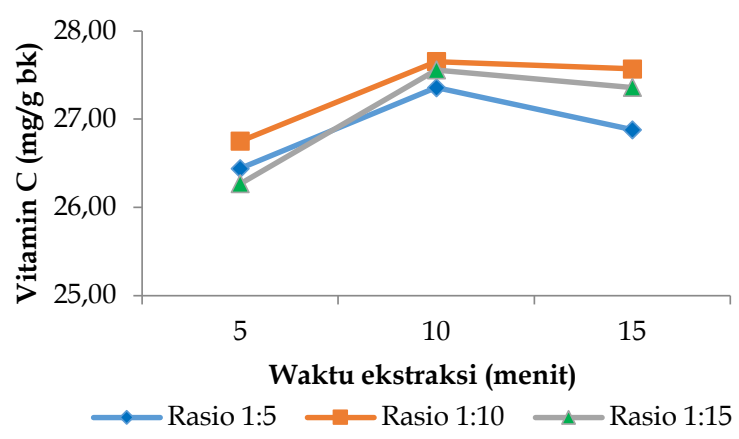

(d)

Gambar 1. Pengaruh rasio bahan:pelarut dan lama waktu ekstraksi terhadap rerata kandungan capsaisinoid (a), total fenol (b), flavonoid (c) dan vitamin C (d) ekstrak cabai rawit metode UAE

Kandungan vitamin $\mathrm{C}$ atau asam askorbat tidak menunjukkan perbedaan yang signifikan akibat penambahan jumlah pelarut. Asam askorbat merupakan senyawa yang bersifat polar dan dapat larut dengan baik dalam pelarut polar (aquades). Sedangkan dalam proses ekstraksi ini, pelarut yang digunakan adalah etanol yang bersifat semipolar. Oleh karena itu, penambahan jumlah pelarut tidak akan membuat perbedaan hasil yang signifikan. Kelarutan vitamin C dalam air sebesar $330 \mathrm{~g} / \mathrm{L}$, sedangkan dalam etanol sebesar $20 \mathrm{~g} / \mathrm{L}$. Selain itu, kemungkinan vitamin $\mathrm{C}$ dalam ekstrak telah mengalami kerusakan akibat proses pemekatan ekstrak. Proses ini dilakukan menggunakan rotary evaporator, digunakan suhu $40{ }^{\circ} \mathrm{C}$, sehingga memungkinkan terjadi penurunan hasil bagi senyawa termolabil seperti vitamin C. Menurut N1joku et al. (2011), kadar vitamin $C$ pada air jeruk nipis, anggur, jeruk dan lemon mengalami penurunan 3-10\% dari $20^{\circ} \mathrm{C}$ hingga $40{ }^{\circ} \mathrm{C}$. Walaupun kandungan vitamin $C$ meningkat dengan bertambahnya jumlah pelarut, akan tetapi dibutuhkan waktu yang lebih lama dalam proses penguapan pelarut. Akibatnya tingkat kerusakan vitamin C juga semakin besar. Oleh karena itu, penambahan jumlah pelarut tidak menunjukkan perbedaan yang signifikan terhadap kandungan vitamin $\mathrm{C}$. 
Tabel 1. Rerata kandungan capsaicinoid, total fenol, flavonoid dan vitamin C ekstrak akibat perbedaan rasio bahan:pelarut $(\mathrm{mg} / \mathrm{g}$ bk)

\begin{tabular}{ccccc}
\hline $\begin{array}{c}\text { Waktu } \\
\text { (menit) }\end{array}$ & $\begin{array}{c}\text { Capsaicinoid } \\
\text { (mg/g bk) }\end{array}$ & $\begin{array}{c}\text { Fenol } \\
\text { (mg GAE/g bk) }\end{array}$ & $\begin{array}{c}\text { Flavonoid } \\
\text { (mg QE/g bk) }\end{array}$ & $\begin{array}{c}\text { Vitamin C } \\
\text { (mg/g bk) }\end{array}$ \\
\hline $1: 5$ & $96,64 \mathrm{~b}$ & $47,80 \mathrm{~b}$ & $107,49 \mathrm{~b}$ & 26,89 \\
$1: 10$ & $108,92 \mathrm{a}$ & $53,59 \mathrm{a}$ & $191,87 \mathrm{a}$ & 27,32 \\
$1: 15$ & $105,52 \mathrm{ab}$ & $52,33 \mathrm{a}$ & $194,00 \mathrm{a}$ & 27,06 \\
\hline BNJ & 9,41 & 2,62 & 14,78 & 1,91
\end{tabular}

Keterangan: angka yang didampingi huruf yang sama dalam satu kolom menunjukkan hasil yang tidak berbeda nyata $(\mathrm{p}<0,05)$

\section{Pengaruh Lama Waktu Ekstraksi}

Hasil analisa ragam menunjukkan bahwa faktor lama waktu ekstraksi berpengaruh nyata terhadap kandungan capsaisinoid, total fenol dan flavonoid ekstrak. Sebaliknya, faktor lama waktu ekstraksi tidak berpengaruh nyata terhadap kandungan vitamin $C$ ekstrak. Rerata kandungan capsaisinoid, total fenol, flavonoid dan vitamin $C$ ekstrak cabai rawit akibat perbedaan lama waktu ekstraksi dapat dilihat pada Tabel 2.

Kandungan capsaicinoid ekstrak mengalami penurunan dengan bertambahnya waktu ekstraksi. Pola tersebut juga ditunjukkan oleh Barbero et al. (2008) dimana ekstraksi capsaicin menggunakan UAE memberikan hasil yang tidak berbeda nyata untuk waktu ekstraksi antara 5 hingga 25 menit, dan terjadi penurunan antara waktu 10 hingga 20 menit. Penurunan jumlah ini dapat disebabkan akibat kerusakan senyawa capsaisin oleh radikal bebas. Pada proses ekstraksi metode UAE, terdapat kemungkinan terbentuk radikal bebas yang dapat mengikat senyawa bioaktif sehingga menurunkan jumlah senyawa bioaktif (Pradana et al., 2017). Menurut Leong et al. (2011), adanya tekanan dan suhu ekstrem serta pecahnya gelembung kavitasi, akan menghasilkan radikal bebas. Dalam air, radikal bebas hidroksi dan hidroksil terbentuk karena pembelahan homolitik. Semakin lama waktu ekstraksi, maka jumlah radikal bebas yang terbentuk semakin banyak. Akibatnya semakin besar penurunan senyawa bioaktif seperti capsaicin.

Penurunan kandungan capsaisinoid juga disebabkan karena terjadi degradasi enzimatis senyawa capsaisinoid oleh enzim peroksidase. Menurut Wang et al. (2010), setelah jaringan seluler buah dirusak, maka capsaisin dan dihidrocapsaisin akan berkurang akibat degradasi oleh enzim peroksidase. Bagian dari capsaicin dan dihidrocapsaisin yang mudah teroksidasi oleh enzim tersebut adalah gugus vanilyl. Enzim peroksidase merupakan enzim yang tahan terhadap panas. Pemberian perlakuan panas hingga suhu $90{ }^{\circ} \mathrm{C}$ tidak mengurangi aktivitas enzim tersebut. (Irfan et al., 1998). Oleh karena itu, semakin lama waktu ekstraksi maka semakin lama terjadi kontak antara capsaisinoid dan enzim peroksidase, sehingga terjadi penurunan kadar capsaisin capsaisinoid.

Total fenol dan flavonoid menunjukkan pola yang berbeda dengan kandungan capsaisinoid, yaitu mengalami peningkatan hasil dengan bertambahnya waktu ekstraksi (setelah menit ke 15 untuk senyawa fenol dan menit ke 10 untuk senyawa flavonoid). Hal yang sama juga ditemukan oleh Rahmawati dan Putri (2013). Adanya proses kavitasi akan mampu merusak dinding sel dan melepaskan senyawa yang terkandung didalam sel dengan cepat, dan selanjutnya terjadi perpindahan massa dari matriks sel menuju pelarut melalui proses difusi. Proses ini akan terus berlangsung dan meningkatkan hasil ekstraksi sampai terjadi titik kesetimbangan dimana konsentrasi fenol di dalam dan di luar sel sama (Pradana et al., 2017). Oleh karena itu, sebelum terjadi titik kesetimbangan konsentrasi, maka penambahan waktu ekstraksi akan meningkatkan jumlah senyawa terekstrak. Hal yang sama juga ditunjukkan oleh $\mathrm{Xu}$ et al. (2015), dimana difusi senyawa bioaktif dari bahan ke pelarut dapat ditingkatkan dan keseimbangan larutan dapat dicapai dalam waktu yang singkat yaitu pada menit ke 15 .

Berdasarkan Tabel 2. kandungan vitamin $C$ ekstrak tidak menunjukkan perbedaan signifikan dengan bertambahnya waktu ekstraksi. Hal ini disebabkan karena asam askorbat merupakan senyawa yang bersifat polar dan dapat larut dengan baik dalam pelarut polar (aquades). Sedangkan dalam proses ekstraksi ini, pelarut yang digunakan adalah etanol yang bersifat 
semipolar. Oleh karena itu, penambahan waktu ekstraksi tidak memberikan perbedaan hasil yang signifikan. Kelarutan vitamin C dalam air sebesar $330 \mathrm{~g} / \mathrm{L}$, sedangkan dalam etanol sebesar $20 \mathrm{~g} / \mathrm{L}$ (Anonymous, 2016). Kecilnya jumlah vitamin $\mathrm{C}$ didalam ekstrak, diduga karena telah terjadi kerusakan selama proses ekstraksi akibat peningkatan suhu, dimana suhu akhir proses berkisar $36-37{ }^{\circ} \mathrm{C}$. Kerusakan akibat suhu juga terjadi selama proses penghilangan pelarut menggunakan rotary evaporator pada suhu $40{ }^{\circ} \mathrm{C}$. Menurut
Njoku et al. (2011), kadar vitamin C pada air jeruk nipis, anggur, jeruk dan lemon mengalami penurunan $3-10 \%$ dari $20{ }^{\circ} \mathrm{C}$ hingga $40^{\circ} \mathrm{C}$. Selain itu, penurunan juga dapat terjadi karena oksidasi akibat radikal bebas yang terbentuk selama proses kavitasi. Semakin lama waktu ekstraksi maka semakin banyak kandungan vitamin C yang teroksidasi oleh radikal bebas tersebut. Bae et al. (2013) juga mengemukakan bahwa laju degradasi asam askorbat lebih cepat dibandingkan capsaicinoid.

Tabel 2. Rerata kandungan capsaicinoid, total fenol, flavonoid dan vitamin C ekstrak UAE akibat perbedaan lama waktu ekstraksi (mg/g bk).

\begin{tabular}{lcccc}
\hline Waktu (menit) & $\begin{array}{c}\text { Capsaicinoid } \\
\text { (mg/g bk) }\end{array}$ & $\begin{array}{c}\text { Fenol } \\
\text { (mg GAE/g bk) }\end{array}$ & $\begin{array}{c}\text { Flavonoid } \\
\text { (mg QE/g bk) }\end{array}$ & $\begin{array}{c}\text { Vitamin C } \\
\text { (mg/g bk) }\end{array}$ \\
\hline 5 & $107,62 \mathrm{a}$ & $49,12 \mathrm{~b}$ & $143,89 \mathrm{~b}$ & 26,49 \\
10 & $106,35 \mathrm{ab}$ & $50,24 \mathrm{~b}$ & $171,74 \mathrm{a}$ & 27,52 \\
15 & $97,12 \mathrm{~b}$ & $54,38 \mathrm{a}$ & $177,74 \mathrm{a}$ & 27,27 \\
\hline BNJ & 9,41 & 2,62 & 14,78 & 1,91 \\
\hline
\end{tabular}

Keterangan: angka yang didampingi huruf yang sama dalam satu kolom menunjukkan hasil yang tidak berbeda nyata $(\mathrm{p}<0,05)$

\section{Penentuan Perlakuan Terbaik}

Penentuan perlakuan terbaik dilakukan menggunakan metode multiple attribute. Parameter yang digunakan adalah kandungan capsaisinoid, total fenol, flavonoid dan vitamin C. Nilai yang diharapkan untuk semua parameter adalah nilai maksimal. Perlakuan terbaik yang terpilih dari ekstrak kasar cabai rawit akibat perlakuan waktu ekstraksi dan rasio bahan:pelarut adalah perlakuan lama waktu ekstraksi 15 menit dan rasio bahan:pelarut 1:10. Perlakuan terbaik tersebut memiliki karakteristik sebagai berikut: kandungan capsaicin $102,89 \mathrm{mg} / \mathrm{g}$ bk, total fenol 56,75 mg GAE/g bk, total flavonoid 208,89 mg QE/g bk dan kandungan vitamin C $27,57 \mathrm{mg} / \mathrm{g}$ bk.

\section{Aktivitas Antioksidan dari Perlakuan Terbaik}

Aktivitas antioksidan berkaitan dengan adanya berbagai metabolit sekunder didalam tanaman seperti alkaloid, flavonoid, isoflavonoid, tanin, coumarin, glikosida, terpen dan senyawa fenolik memiliki sifat antioksidan (Gurnani et al., 2016). Zimmer (2012) menunjukkan bahwa asam askorbat memiliki aktivitas antioksidan tertinggi, kemudian diikuti oleh quercetin dan capsaicin. Sricharoen et al., (2016) juga menunjukan kekuatan aktivitas antioksidan dalam bentuk
$\mathrm{IC}_{50}$ dari dihidrocapsaicin $(17,21 \pm 0,25 \mu \mathrm{g} / \mathrm{ml})<$ capsaicin $(14,51 \pm 0,57 \mu \mathrm{g} / \mathrm{ml})<$ quercetin $(2,49 \pm 0,23 \mu \mathrm{g} / \mathrm{ml})<$ asam galat $(0,90 \pm 0,04$ $\mu \mathrm{g} / \mathrm{ml})$.

Aktivitas antioksidan perlakuan terbaik ekstrak cabai rawit dalam bentuk $\mathrm{IC}_{50}$ sebesar $527,29 \mathrm{ppm}$. Sedangkan nilai IC Co $_{50}$ standar asam askorbat sebesar 10,88 ppm. Aktivitas antioksidan ekstrak cabai rawit tergolong rendah. Rendahnya aktivitas antioksidan ini dapat disebabkan karena sebagian besar senyawa penyusun ekstrak adalah total flavonoid dan capsaicin, dimana kedua senyawa ini memiliki aktivitas antioksidan yang rendah. Sedangkan total fenol dan vitamin $C$ yang memiliki aktivitas antioksidan kuat hanya terdapat dalam jumlah sedikit. Dahmoune et al. (2014) juga menunjukkan bahwa pada proses ekstraksi menggunakan metode UAE, terdapat kemungkinan terbentuk radikal bebas yang dapat mengikat senyawa bioaktif, sehingga akan menurunkan sifat antioksidan ekstrak.

Selain itu, faktor penyebab rendahnya aktivitas antioksidan ekstrak adalah karena ekstrak merupakan ekstrak kasar dan dalam keadaan tidak murni seperti standar asam askorbat. Diduga senyawa bioaktif yang bersifat antioksidan seperti capsaicinoid, fenol, flavonoid dan vitamin $\mathrm{C}$ berikatan dengan gugus lain, misalnya glikosida. Glikosida 
adalah senyawa yang tersebar luas di dalam tanaman (Mikamo et al., 2000). Hal tersebut mengakibatkan senyawa bioaktif tidak mampu menjadi donor hidrogen dan elektron untuk menangkap radikal bebas.

\section{SIMPULAN}

Rasio bahan:pelarut dan lama waktu ekstraksi memberikan perbedaan hasil yang signifikan terhadap kandungan capsaisinoid, total fenol dan flavonoid. Perlakuan terbaik diperoleh dari rasio bahan:pelarut 1:10 dan lama waktu ekstraksi 15 menit, dengan karakteristik: kandungan capsaisin 102,89 $\mathrm{mg} / \mathrm{g}$ bk, total fenol 56,75 mg GAE/g bk, total flavonoid 208,89 $\mathrm{mg}$ QE/g bk dan kandungan vitamin C $27,57 \mathrm{mg} / \mathrm{g}$ bk, serta nilai IC 50 sebesar 527,29 ppm.

\section{DAFTAR PUSTAKA}

Alupului, -A., 2012. Microwave extraction of active principles from medicinal plants. U.P.B. Science Bulletin, Series B 74(2), 2914. https://www.scientificbulletin. upb.ro/rev_docs_arhiva/fullf4b_14141 3.pdf

Atanassova, -M., Georgieva, -S., Ivancheva, K., 2011. Total phenolic and total flavonoid contents, antioxidant capacity and biological contaminants in medicinal herbs. Journal of the University of Chemical Technology and Metallurgy. $\quad 46(1), \quad 81-88$. https://dl.uctm.edu/journal/node/j20 11-1/12_Maria_Atanasova.pdf

Azmir, -J., Zaidul, -I., Rahman, -M., Sharif, -K., Mohamed, -A., Sahena, -F., Jahurul, -M., Ghafoor, -K., Norulaini, -N., Omar, -A. 2013. Techniques for extraction of bioactive compounds from plant materials: a review. Journal of Food Engineering. 117(4), 426-436. http://fac.ksu.edu.sa/sites/default/fil es/23-jfe_117_2013.pdf

Bae, -H., Jayaprakasha, -G.K., Jifon, -J., Patil, B.S., 2012. Variation of antioxidant activity and the levels of bioactive compounds in lipophilic and hydrophilic extracts from hot pepper (Capsicum spp.) cultivars. Food
Chemistry. 134(4), 1912-1918. https:// doi.org/10.1016/j.foodchem.2012.03.10 8

Barbero, -G., Liazid, -A., Palma, -M., Barroso, C. 2008. Ultrasound-assisted extraction of capsaicinoids from peppers. Talanta. 75(5), 1332-1337. https://doi.org/10.1016/j.talanta.2008. 01.046

Boonkird, -S., Phisalaphong, -C. Phisalaphong, -M., 2008. Ultrasoundassisted extraction of capsaicinoids from Capsicum frutescens on a lab-and pilotplant scale. Ultrasonics Sonochemistry. 15(6):1075-1079. https:// doi.org 10.1016/j.ultsonch.2008.04.010

Dahmoune, -F., Spigno, -G., Moussi, -K., Remini, -H., Cherbal, -A., Madani, -K., 2014. Pistacia lentiscus leaves as a source of phenolic compounds: Microwaveassisted extraction optimized and compared with ultrasound-assisted and conventional solvent extraction. Industrial Crops and Product. 61, 31-40. https://doi.org/10.1016/j.indcrop.2014 .06 .035

De Aguiar, -A.C., Sales, -L.P., Coutinho, -J.P., Barbero, -G.F., Godoy, -H.T., Martínez, J., 2013. Supercritical carbon dioxide extraction of Capsicum peppers: global yield and capsaicinoid content. The Journal of Supercritical Fluids. 81, 210-216. https://doi.org/10.1016/j.supflu.2009.0 7.008

Depkes. 2005. Daftar Komposisi Bahan Makanan. Piranti Lunak NutriClin versi 2.0 edisi kedua, Subdit Gizi Klinis, Departemen Kesehatan Indonesia, Jakarta

Emmanuel-Ikpeme, -C., Henry, -P., Okiri, -O A. 2014. Comparative evaluation of the nutritional, phytochemical and microbiological quality of three pepper varieties. Journal of Food Nutrition and Sciences. 2(3), 74-80. https://doi.org/10. 11648.j.jfns.20140203.15

Gurnani, -N., Gupta, -M., Shrivastava, -R., Mehta, -D., Mehta, -B.K., 2016. Effect of extraction methods on yield, phytochemical constituents, antibacterial and antifungal activity of Capsicum frutescens L. Indian Journal of Natural Products and Resources (IJNPR)[Formerly Natural Product 
Radiance (NPR)]. 7(1), 32-39. http://op.niscair.res.in/index.php/IJN PR/article/viewFile/9138/700

Irfan, -I., Pawelzik, -E., Luecke, -W. 1998. The use of microwave to inativate enzymes in rape seeds. Proceedings of the 7 th International Working Conference on Stored product Protection. 7(2):1667-1670. https://spiru.cgahr.ksu.edu/proj /iwcspp/pdf2/7/1667.pdf

Kim, -K.S., Koo, -M.S., Jeon, -J.W., Park, -H.S., Seung, -I.S., 2002. Capsicum plaster at the Korean hand acupuncture point reduces postoperative nausea and vomiting after abdominal hysterectomy. Anesthesia \& Analgesia. 95(4), 1103-1107. https://doi.org/10.1097/00000539-2002 10000-00059

Knotkova, -H., Pappagallo, -M., Szallasi, -A. 2008. Capsaicin (TRPV1 Agonist) therapy for pain relief: farewell or revival?. The Clinical Journal of Pain. 24(2), 142-154. https://doi.org/ AJP.0b013e318158ed9e

Leong, -T., Ashokkumar, -M., Kentish, -S., 2011. The fundamentals of power ultrasound-a review. Acoust. Aust. 39(2):54-63. http://hdl.handle.net/ 11343/123494

Luo, -X.J., Peng, -J., Li, -Y.J., 2011. Recent advances in the study on capsaicinoids and capsinoids. European Journal of Pharmacology. 650(1), 1-7. https://doi.org/10.1016/j.ejphar.2010.0 9.074

Mikamo E, -Y. Okada, -A. Semma, -Y. Otto, Morimoto, -I. 2000. Studies on structural correlation-ship with antioxidant activity of flavonoids. Japanees Journal of Food Chemistry and safety. 7(2), 93-96. https://doi.org/10.18891/jjfcs.7.2_93

Nascimento, -P.L., Nascimento, -T.C., Ramos, N.S., Silva, -G.R., Gomes, -J.E.G., Falcão, -R.E., Moreira, -K.A., Porto, -A.L., Silva, -T., 2014. Quantification, antioxidant and antimicrobial activity of phenolics isolated from different extracts of Capsicum frutescens (Pimenta Malagueta). Molecules. 19(4), 5434-5447. https://doi.org/10.3390/molecules190 45434

Njoku, -P.C., Ayuk, -A.A., Okoye, -C.V., 2011. Temperature effects on vitamin C content in citrus fruits. Pakistan Journal of Nutrition. $\quad 10(12), \quad 1168-1169$. https://doi.org/10.3923/pjn.2011.11 68.1169

Park, -H.S., Kim, -K.S., Min, -H.K., Kim, -D.W., 2004. Prevention of postoperative sore throat using capsicum plaster applied at the Korean hand acupuncture point. Anaesthesi. 59(7):647-651. https://doi.org./10.1111/j.1365-2044.20 2004.03739.x

Pradana, -F. A., Khoirul, -M. D., Septian -A. 2017. The effectiveness Test of Ultrasonic Extraction Microwave Distillation (USE-MD) Method in Capsaicin Extraction. IPTEK, Journal of Engineering. 3(1), 6-10. https://doi.org/ 10.12962/joe.v3i1.2265

Rahmawati, -A., Putri, -W.D.R. 2013. Karakteristik ekstrak kulit jeruk bali menggunakan metode ekstraksi ultrasonik (kajian perbandingan lama blansing dan ekstraksi). Jurnal Pangan dan Agroindustri. 1(1). 26-35. https://jpa.ub.ac.id/index.php/jpa/art icle/view $/ 3 / 3$

Selimović, -A., Salkić, -M., Selimović, -A., 2011. Direct spectrophotometric determination of L-ascorbic acid in pharmaceutical preparations using sodium oxalate as a stabilizer. International Journal of Basic $\mathcal{E}$ Applied Sciences. 11(02), 106-109. https://doi.org/10.1.1.419.9203

Sricharoen, -P., Lamaiphan, -N., Patthawaro, P., Limchoowong, -N., Techawongstien, -S., Chanthai, -S., 2016. Phytochemicals in Capsicum oleoresin from different varieties of hot chilli peppers with their antidiabetic and antioxidant activities due to some phenolic compounds. Ultrasonics Sonochemistry. 38,629-639. https://doi.org/10.1016/ j.ultsonch.2016.08.018

Vega-Gálvez, -A., Di Scala, -K., Rodríguez, -K., Lemus-Mondaca, -R., Miranda, -M., López, J., Perez-Won, M. 2009. Effect of air-drying temperature on physicochemical properties, antioxidant capacity, colour and total phenolic content of red pepper (Capsicum annuum, L. var. Hungarian). Food Chemistry.117(4):647-653. http://agris. fao.org/agris-search/search.do?record ID $=$ US201301652895

Victorija -M., Lilijana -K.G., Tatjana -R., Cvetanovska -A., Rubin -G. 2013. 
Jurnal Teknologi Pertanian Vol. 20 No. 2 [Agustus 2019] 79-84

Ekstraksi Senyawa Bioaktif Cabai Rawit [Andayani dkk]

Antioxidative effect of Capsicum oleoresins compare with pure capsaicin. Journal of Pharmacy. 4(11), 44-48. https:/ / 10.9790/3013-0411044048

Wang, -Y.L., Xi, -G.S., Zheng, -Y.C., Miao, -F.S. 2010. Microwave-assisted extraction of flavonoids from Chinese herb Radix puerariae (Ge Gen). Journal of Medicinal Plants Research. 4(4), 304-308. http://www.academicjournals.org/ap p/webroot/article/article1380526817 Wang\%20et\%20al.pdf

Whiting, -S., Derbyshire, -E. Tiwari, -B. 2012. Capsaicinoids and capsinoids. A potential role for weight management? A systematic review of the evidence. Appetite. 59(2), 341-348. https://doi.org /10.1016/j.appet.2012.05.015

Xu, -D.P., Zhou, -Y., Zheng, -J., Li, -S., Li, -A.N., Li, -H.B., 2015. Optimization of ultrasound-assisted extraction of natural antioxidants from the flower of Jatropha integerrima by response surface methodology. Molecules. 21(1), 18. https://doi.org/10.3390/molecules 21010018

Yang, -Z.H., Wang, -X.H., Wang, -H.P., Hu, L.Q., Zheng, -X.M., Li, -S.W., 2010. Capsaicin mediates cell death in bladder cancer T24 cells through reactive oxygen species production and mitochondrial depolarization. Urology. 75(3), 735741. https://doi.org/10.1016/j.urology .2009 .03 .042

Zeleny, -M. 1982. Multiple Criteria Decision Making. Mc Graw Hill, New York

Zhang, -G., He, -L. Hu, -M., 2011. Optimized ultrasonic-assisted extraction of flavonoids from Prunella vulgaris L. and evaluation of antioxidant activities in vitro. Innovative Food Science \& Emerging Technologies. 12(1):18-25. https//doi.org /10.1016/j.ifset.2010.12.003

Zhuang, -Y., Chen, -L., Sun, -L. and Cao, -J., 2012. Bioactive characteristics and antioxidant activities of nine peppers. Journal of Functional Foods. 4(1), 331-338. https://doi.org/10.1016/j.jff.2 012.01.001

Zimmer, -A.R., Leonardi, -B., Miron, -D., Schapoval, -E., De Oliveira, -J.R., Gosmann, -G. 2012. Antioxidant and antiinflammatory properties of Capsicum baccatum: from traditional use to scientific approach. Journal of Ethnopharmacology. 139(1), 228-233. https://doi.org/10.1016/ j.jep.2011.11.005 